\title{
GERERAL, INTORMATION
}

Some of the publications in this list have appeared in the regular series of the rational Burear of Standards. Where the price is stated, the publicat tion may be purchased from the Superintendent of Documents by remitting either coupons obtainable from hin in sets of 20 for $\$ 1.00$ and good until used, or check or Isoney order made payable to the Superintendent of Documents, Governnent Printing Cffice, Washington 25, D. C.

Publications listed as free may be obtained from the National Bureau of Standards.

Series letters with serial nubers are used to designate Bureau publications:

BH Building and Iousing publication

BVS Building laterials and Structures publication

IC Letter Circular

iv Miscellaneous publication

Circular 624 and supplenents (a complete list of Bureau's publications) is sold by the Superintend snt of. Documents for $\$ 1.30$. Announcement of $\mathrm{ner}$ Bureau publications is made each month in the Tecinical Nows Bulletin, obtainable by subscription, from the superintendent of Documents, at 50 cents per year.

\section{Title}

\section{BUITDING CODSS}

Preparation and revision of building codes (1939)............ Bissig $15 \phi$ Buil ding code requiraments for new dweling construction (1947)

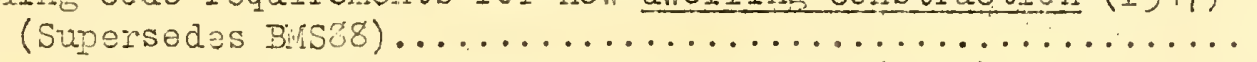
Racomended minimun requirements for pluzbing (1932)........... Anerican standard building code requirenents for


Fire-resistance clas sifications of building construction (1942). dnerican standard building code raquirenents for minirum

desim loads in buil dines and other structures (1945).....


Iist of problished matericil relating to building

regulation (1947)

BirSI07 20ф BII 3

in. 74

BMSg2

讧 79

1751

847 ICset Free 
Title

Building materials, building standards, home building:

Publications of the National Bureau of Standards

(list)

(1940)...

IC592

Free

Suppl ment to I, C592

(1941).

IC592 Suppl.

$T 0$

$\%$

Building naterials and structures reports (list) (1945)........ IC800 Free

Building naterials and structures reports subject list.......... SI Free

Care and repair of the house $(1931) \ldots \ldots \ldots \ldots \ldots \ldots \ldots$. BHI 5 . 20 .



Hone haating problems: Iist of publications and articles (1946).. IC840 Free

House Plan Services (list of agencies) (1946).............. I C829 Free

List of published material relating to hore building and

maintenance (including the more important National

Bureau of Standards publications on subjects covered) (1946). IC830 Free

Standards and specificaticins for building, and construction

materials, fixtures, supplies, and equiprent (list) (1945)... IC808 Free

Suggestions for possible repairs aid itprovements in the

house and its equipment (check list) (1931)............. Ck-Sug Free

Tecimical information on building naterials (list) (1944).... TIBM(Iist) Free

\section{MISCZII AIEOUS IISTS OF RUBL ICATI ONS}

Iists of publications of interest to the general public (194ą).... Ic6g6 "Free Publications of interest to suburbanites and home-builders

(Price Iist 72, Supt. of Docunents)

(1947) Fi 72 Free 